\title{
Grundtvigs skoletanker i Filippinerne
}

\author{
Af Lilian Zøllner
}

I 1991 blev der taget initiativ til at forsøge oprettet en højskole funderet på Grundtvigs skoletanker i Filippinerne. Højskoleprojektet blev støttet med midler fra Folkekirkens Nødhjælp og Danida, men som det fremgår af nedenstående var der grund til bekymring:

»...En nok så væsentlig risiko er den politiske situation i landet. En forudsætning for projektets fortsættelse er, at græsrodslederne kan blive i deres lokalsamfund, arbejde åbent/legalt, og at de forbliver i live. $\ll^{1}$

Udsagnet rummer i al sin enkelthed de arbejdsvilkår såvel initiativtager, leder og lærere på det tidspunkt arbejdede og stadig arbejder under - nemlig med livet som indsats. Men hvad lå til grund for initiativet? Hvem var initiativtager? Hvordan kunne Grundtvigs skoletanker finde vej til Filippinerne? Og hvilke udfordringer ville en evt. kommende højskole stå overfor?

\section{Tilbageblik}

Den 13. december 1974 blev den katolske præst Edicio de la Torre arresteret af Marcosregimet for at være én af NDF's ledere (»Den Nationale Demokratiske Front «). I indledningen til den bog, ${ }^{2}$ som trods fængsling alligevel blev skrevet, og som trods undtagelsestilstand alligevel blev udgivet, skriver han om de tanker og overvejelser, der var centrale for ham under fængselsopholdet:

»En sultestrejke mod tortur og vilkårlige arrestestationer medførte, at jeg blev idømt syv måneders isolation, og ligesom andre fanger $\mathrm{i}$ isolation havde jeg alt for mange timer, som gik alt for langsomt.

At tænke var den nemmeste måde at udfylde de mange dage og nætter, - og det var umuligt at lade være. Jeg var bekymret for alt det ugjorte arbejde og for de kammerater, som nu måtte omgruppere sig og finde nye mødesteder. Den tidlige eftermiddagshede tvang mig til min metalfeltseng, hvor jeg - stir- 
rende op i loftet - talte spindelvæv og takkede edderkopperne for at fange de forbistrede myg, og hvor jeg, før jeg langsomt faldt i søvn, spekulerede på, hvor mange der tænkte sådan om et fængsel. Solnedgangen var altid et trist tidspunkt på trods af de stærke farver, skabt gennem de mørke tremmer i vinduet (...)

Natten bragte altid vores mange sange og digte i erindring dem om friheden, som helt sikkert ville bryde frem i lyset, ligemeget hvor langt mørket end skulle vare. Jeg ville $\emptyset$ nske, at kampen også var så enkel. Solen står op, ligemeget om vi er vågne eller sover; men friheden behøver folk til at holde vagt hele natten og til at ruske andre op, selvom de gør vrøvl i starten.

Ofte tænkte jeg på venner og kammerater fra kampen, specielt dem, som jeg bedst kunne identificere mig med - middelklassekristne, som skabte overgangen fra reformisme til revolution fra midten af $60^{\prime}$ erne til midten af $70^{\prime}$ erne. Vi var nok til at kunne kalde os en generation - endda første generation, for den næste generation var allerede begyndt, - dem vi døbte "børn af undtagelsestilstanden'.

Jeg mente, at vi burde fortælle vores historie til denne generation af børn af undtagelsestilstanden. Vi havde en luksus, som de ikke havde, nemlig åbent at kunne undersøge alle mulige teologiske og politiske alternativer uden for tidligt at være nødt til at vælge imellem kompromis og illegalitet. Vi havde også det privilegium - og samtidig den byrde - at skulle træde helt nye stier; og mens de stadig skulle vælge deres egen sti, havde de stadig ret til at forvente at få nogle nyttige ideer fra vores generation.

Der er også en anden gruppe mennesker, som vi skylder at fortælle vores historie - nemlig venner, slægtninge og allierede (her og i udlandet ), som, selvom de måske ikke altid forstod os, sympatiserede med os, og som støttede os alle disse år uden at vi havde gjort os fortjent til det. Vi havde den alt for udbredte svaghed, at aktivisterne brugte alt for meget tid på tålmodigt at forklare os over for fremmede og samtidig forventede, at de, som kendte os, uden videre skulle kunne acceptere vore idéer. Måske fandt vi det for svært at oversætte de formulerede problemer og muligheder fra det ene sprog til det 
andet, problemer, som vi så nemt diskuterede i offentlige sammenhænge. Ikke engang den litteratur, vi gav dem, hjalp altid, for bevægelsens skriverier var temmelig verdslige, endog marxistiske; og de lejlighedsvise kristne passager kunne ikke altid skjule den skærende tone, som mere afspejlede vores vrede end det håb, som vi burde gøre rede for »med mildhed og respekt « (1. Peter 3,16$) \ll^{3}$

Edicio de la Torre blev født d. 11. juli 1943. I 1964 afsluttede han sine studier i filosofi og begyndte at undervise gymnasielever i latin, engelsk og filippinsk. En opfordring til at læse teologi i Rom blev afslået ud fra en betragtning om, at et arbejde inden for kirken automatisk ville føre til politiske aktiviteter. Mange præster i den katolske kirke var allerede indblandet $\mathrm{i}$ de folkelige bevægelser og søgte at støtte den fattige bondebefolkning i dens forsøg på at få indført et folkestyre.

Men det politiske sprog var endnu fremmed for Edicio de la Torre. "Jeg havde en vag idé om at hjælpe med til at udvikle den filippinske teologi, og jeg mente, at jeg havde større mulighed for at gøre dette, hvis jeg blev i Filippinerne. Muligvis havde forberedelserne til at fejre 400-året for kristendommens indførelse (1565 -1965) noget med min beslutning at gøre. $\aleph^{4}$

I begyndelsen af sit teologiske studium havde Edicio de la Torre ikke blik for de politiske, $\varnothing$ konomiske eller sociale problemer $\mathrm{i}$ landet, han var snarere optaget af den filippinske kultur. Imidlertid begyndte der langsomt at rejse sig en del overvejelser. Et par unge teologistuderende bebrejdede en biskop, at den katolske kirke sov. De pegede på, at den katolske kirke ikke havde blik for de sociale uretfærdigheder, der var i landet, og at den katolske kirke ikke aktivt gik ind i kampen mod overtrædelse af menneskerettighederne. Biskoppen svarede, at den katolske kirke ganske vist sov, men at det ville være muligt at vække den. Den ene mulighed ville være at vække den ved at råbe højt, en anden mulighed ville være at vække den mere blidt. »Jeg overvejede de forskellige måder, vi vågner på. Nogle vågner $\varnothing$ jeblikkeligt, andre vågner lidt efter lidt. Øjnene og tankerne er klare, men kroppen sover stadig." Biskoppen gav udtryk for, at kirken var mere vågen, end de de studerende troede, men at den stadig ikke var stået ud af sengen. 
Edicio de la Torre begyndte sammen med de $\emptyset$ vrige studerende at stille spørgsmål om, hvad de var for, og hvad de var imod, og hvilke skridt de fremover ville tage. Imidlertid kunne de ikke præsentere nogle klare retningslinier, men de begyndte som det første skridt at overveje, hvad de positivt kunne gå ind for.

Begrundelsen for, at det var så vanskeligt at få formuleret klare retningslinier for handling var, at Edicio under hele sit tidligere forløb og studier havde søgt generelle svar på, hvad der var kendetegnende for den filippinske kultur, og hvilke værdier der lå til grund for den filippinske identitet. Studierne gav anledning til indgående debatter med andre teologistuderende, og under disse debatter blev det muligt at formulere egne visioner og egne håb. Grundlaget var altid boglige studier, og ofte var bøgerne skrevet af udenlandske forfattere, som havde analyseret den filippinske kultur og identitet.

Langsomt erkendte Edicio, at grundlaget for handling i stedet måtte være at stille spørgsmål. Ikke spørgsmål om filippinerne som en samlet befolkning eller masse, men spørgsmål til den enkelte filippiner. Derved blev han tvunget til at se bagom de skrevne ord og i stedet anvende en mundtlig tilgang. Samtale og debatter med den enkelte filippiner var det fundamentale grundlag, som i stedet måtte give anledning til at pege på mulige veje at gå.

Da metoden for at finde svarene på de mange spørgsmål ændredes fra de boglige studier til det talte ord, var det også nødvendigt at ændre studiested. Mennesker måtte opsøges der, hvor de var og i det arbejde, de kæmpede for. Det nye studiemiljø var meget anderledes end det tidligere, hvor han havde beskæftiget sig med »ord uden kød og blod." Ved at opsøge mennesker i deres hjem, ved at opleve de livsvilkår, de levede under og ved at lytte til deres ord, begyndte der langsomt at tegne sig nogle billeder. De spørgsmål, disse mennesker stillede, drejede sig om, hvordan de kunne ændre deres håbløse situation, og hvordan de kunne kæmpe for retfærdighed. Deres spørgsmål drejede sig ikke om, hvilke værdier der lå til grund for den filippinske kultur, de drejede sig i stedet om de helt konkrete ting, der havde med deres overlevelse at gøre. 
Proest

I 1968 blev Edicio de la Torre færdig med sin teologiske uddannelse og blev konfronteret med spørgsmål om kirkens rolle i samfundet. Overvejelserne om en socialreform gav anledning til at indkalde de katolske biskopper til en konference. Begrundelserne var bl.a., at den katolske kirke siden 1967 havde igangsat mere end 2000 projekter, som alle havde til formål at ændre ved de vilkår, de fattige levede under. Imidlertid ville problemerne ikke alene kunne løses gennem projekter. Der måtte en socialreform til, som kunne ændre ved hele grundlaget for fordelingen af de $\varnothing$ konomiske ressourcer. I 1969 blev $65 \%$ af bruttonationalindkomsten fordelt på kun $2.6 \%$ af befolkningen. Den restende del af de mange millioner indbyggere (68 millioner) måtte dele $22 \%$ af bruttonationalindkomsten, og de restende $13 \%$ gik til regeringen.

Af Edicio de la Torres overvejelser om hvorvidt den katolske kirke og præsterne skulle indgå i arbejde for en socialreform fremgår det, at man med rette kunne stille spørgsmål om, hvorvidt en teolog var uddannet til dette arbejde, som retteligt burde ligge hos regeringen eller hos borgerne. Edicio besvarer spørgsmålet med følgende: »En præst er først og fremmest kristen og menneske. Problemet vedrører enhver kristen og ethvert menneske i dette land. Vi kan ikke tillade os at svare, som en teologisk professor gjorde, da han blev stillet over for spørgsmålet om, hvorfor han ikke bekymrede sig om de sociale problemer: Det er ikke mit bord.«

Yderligere en begrundelse for præsternes arbejde med socialreformen blev føjet til: Det sociale problem er ikke kun et $\varnothing$ konomisk eller et politisk problem. Det sociale problem er et moralsk problem. Det er et problem om social retfærdighed. Det drejer sig grundlæggende om, hvem der har retten til at eje jord.

Imidlertid havde præsternes hidtige arbejde bestået $\mathrm{i}$ at deltage $\mathrm{i}$ seminarer og konferencer om den sociale reform. De havde talt til studenter, professionelle og andre kirkelige organisationer. Dette måtte ændres. I stedet skulle der fremover lægges vægt på at lytte til og lære fra de fattige selv. Det var herfra, at svarene på, hvilke handlinger, der skulle iværksættes, skulle gives. Dernæst skulle der arbejdes for at motivere og organisere ledere. Muligvis var præsterne ikke uddannet til at tage disse to opgaver op, men så måtte de lære i takt med opgaverne. 
Præsterne skulle imidlertid ikke stå som eksperterne, der kunne organisere ledere til det folkelige arbejde. Præsten skulle ikke være den $\emptyset$ verste leder for det arbejde, der skulle iværksættes. Derimod måtte hans arbejde bestå $\mathrm{i}$ at have retten og pligten til at udtale sig om de etiske og moralske aspekter, der kunne opstå i et sådant arbejde. Han måtte påtage sig opgaven at motivere, inspirere og opmuntre og have retten til at rådgive på de områder, som han havde specielt kendskab til. Men arbejdets organisering, udførelse og ansvar var først og sidst ledernes.

Med dette som udgangspunkt blev Edicio de la Torre feltpræst for Sammenslutningen af frie Bønder (KKRP). Han forlod senere - i 1972 - dette arbejde med henblik på at bruge sine kræfter på at stifte »Kristne for National befrielse» (CLN), der samme år blev en del af (NDF). Denne organisation arbejdede på at samle de mange organisationer, der støttede den igangværende kommunistledede guerilla.

\section{Fangselsophold}

D. 13 december 1974 blev Edicio de la Torre som nævnt arresteret af Marcos-regimet for at være en af NDF's ledere. Der forelå et meget spinkelt bevis mod ham, men alligevel sad han fængslet indtil 1980, hvorefter han blev løsladt og sendt til Europa for at studere. I 1982 vendte Edicio tilbage til Filippinerne med henblik på at foretage religionssociologiske unders $\varnothing$ gelser, men blev igen arresteret d. 22. april 1983. Sidste fængselsophold varede indtil d. 1. marts 1986, hvorefter han igen forlod Filippinerne. Løsladelsen kom i forbindelse med præsidentskiftet mellem Marcos og Corazon Aquino.

\section{Fortsatte visioner}

Visionerne om at få etableret et reelt folkestyre havde Ed imidlertid stadig. Da han blev løsladt, udtalte han følgende:

»Jeg var glad, selvfølgelig, ikke kun over min egen løsladelse, men også over den lettelse, som Marcos' afrejse betød for hele befolkningen. Men jeg spurgte også mig selv, hvordan den folkelige bevægelse kunne komme videre og definere det demo- 
krati, vi havde kæmpet for, over for de mægtige kræfter, der havde deres egen opfattelse af dette demokrati. $\ll^{5}$

Imidlertid anskuede Edicio det for at være noget problematisk at have tillid til, at der ville blive indført et reelt demokrati samtidig med at Corazon Aquino havde overtaget styret.

Begrundelserne var for det første, at demokratiet var blevet proklameret meget tidligere, end befolkningen havde forventet det. At arbejde og samarbejde ud fra et demokratisk grundlag krævede, at befolkningen var uddannet til og indstillet på at påtage sig de opgaver, der var forbundet med at stå med et selvstændigt ansvar. Netop dette ansvar havde den filippinske befolkning ikke haft mulighed for at indstille sig på, idet den op gennem historien havde været underlagt udefrakommende magthavere, og fordi den under Marcos-styret havde fået frataget alle former for indflydelse. Det havde været meget vanskeligt at få befolkningen organiseret, og uden en vis form for organisering, ville det ikke være muligt at skabe det nødvendige samarbejde mellem mennesker.

Dertil kom, at der var magthavere, som påstod, at demokratiets indførelse udelukkende var et resultat af deres indsats. Derved blev det ikke en folkeopgave at bevare og værne om dette demokrati, men derimod en opgave, som kunne varetages af de få. De væbnede styrker var da heller ikke blevet reduceret sideløbende med, at den nye styreform var blevet proklameret, hvilket kunne tolkes som en mistillid til folket. Venstrefløjens partier var blevet udelukket fra det politiske liv til trods for, at der i et demokrati også måtte være mulighed for at fremkomme med andre og modsatrettede synspunkter end dem, som den ledende præsident eller vedkommendes nærmeste måtte fremkomme med.

Sluttelig var der hverken fra præsidentens side eller fra hendes rådgiveres side interesse $\mathrm{i}$, at folket organiserede sig. Derved ville de kunne få indsigt og indflydelse og komme til at stå som medansvarlige for udviklingen. Men den udvikling, som folket ønskede, var ikke den samme, som Corazon Aquino og hendes rådgivere $\emptyset$ nskede.

Sammen med mange andre udtrykte Edicio ikke blot sine egne betænkeligheder, men holdt samtidig fast ved, at demokratiet var 'en mulig drøm': 
»Vi sagde, at vi ønskede at opbygge et folkeligt demokrati. Vi $\varnothing n s k e d e$ ikke at nøjes med det, der blev tilbudt af vore traditionelle ledere - en simpel genopbygning af et begrænset demokrati for eliten, eller endnu værre, en blanding af demokrati og diktatur.

Den drøm var allerede vanskelig nok at virkeliggøre i 1986. Den er blevet dobbelt så vanskelig i 1988, hvor dødspatruljer og militærstyrker søger at jage det legale venstre ud i illegaliteten og udrydde enhver leder, organisator eller aktivist fra den folkelige bevægelse.

Men vi har intet andet valg end at håbe og derfor kæmpe, i stedet for at fortvivle. Og vi har grund til at håbe og tro, for den folkelige bevægelse er ikke frugten af nogle få dages arbejde. Den er ikke et skøbeligt overfladisk værk. Den har overlevet og er vokset under et diktatur. Den vil overleve, vokse og hjælpe os med at gøre vor drøm til virkelighed. $\ll^{6}$

Edicio de la Torre måtte efter løsladelsen i 1986 forlade landet for at opholde sig i Europa. Edicio de la Torres ophold i Europa gav muligheder for at deltage $\mathrm{i}$ en lang række konferencer og seminarer. I juli 1988 blev han inviteret til at tale ved De danske kirkedage - en konference, som blev afholdt på Grundtvigs Højskole, Frederiksborg. Besøget på højskolen resulterede i møder med mennesker, som fortalte om de danske folkeh $\varnothing$ jskoler og om Grundtvigs skoletanker. Endvidere læste Edicio om højskoletanken og dens betydning gennem tiden.

»Jeg lyttede og læste, men sagde til mig selv, at sådan en skole har vi ikke råd til på Filippinerne. Men alligevel var det, som om jeg fik en følelse af, at dette i virkeligheden var en fjern vision, jeg engang havde haft. Måske kan jeg bedst forklare det ud fra en af mine yndlingssætninger fra Thomas Aquinas, som sagde: «Hvad man end har modtaget, modtages i overensstemmelse med ens evne til at modtage.« I hvert fald greb jeg selve tanken om folkehøjskolen, uden at jeg dermed kunne se nogen mulighed for at få ideen realiseret.«

En af begrundelserne for, at det ville blive vanskeligt at oprette en højskole, var den erfaring, mange af græsrodslederne sad inde med. 
Det arbejde, som i 1970'erne blev gennemført, foregik i samarbejde med kirken. Præster og lærere forsøgte at undervise og organisere bønderne, men st $\varnothing$ dte på advarsler fra en del biskopper. De advarede mod en egentlig oplysning af de fattigste ud fra argumentet om, at der var opbygget så megen vrede i disse mennesker på grund af deres undertrykkelse. De gejstlige pointerede, at der absolut var grunde til deres vrede, men hvis de blev oplyst og organiserede, ville de kunne få en utrolig magt. De ville ikke bruge denne magt til at opnå retfærdighed, men hævn.

Fra græsrodsledemes side var holdningen den, at kirken ikke havde gjort noget væsentlig for at ændre den magtstruktur, der var i landet. Tværtimod havde de implicit været med til at uddanne ledere til 'ansvarlig brug af magt' ved at underst $\varnothing t t e$ det etablerede system. Eliten havde gennem deres uddannelse fået magt, men ikke ansvarlighed over for de svage i samfundet. Elitens 4-årige uddannelsestilbud stod i skærende kontrast til de 3 dages seminar, der var blevet tilbudt de fattigste græsrodsledere én eneste gang i deres liv. Både for præster og for bønderne var det vigtigt, at begrebet ansvarlighed blev forstået som værende andet og mere end en ansvarlighed over for et etableret system. Uddannelse til ansvarlighed måtte bygge på et værdigrundlag, hvor der blev taget hensyn til de svages rettigheder. Det centrale var en debat om ansvarlighed over for hvem eller hvad.

På den baggrund fandt Edicio det vanskeligt at forestille sig, at højskoletanken kunne få en positiv velkomst i de kirkelige kredse, ligesom det var vanskeligt at forestille sig, at magthaverne ville finde drømmen om at uddanne bønder og fiskere frugtbart for deres arbejde.

\section{Besфg i Danmark}

Til trods for alle vanskeligheder dukkede tanken om en højskole alligevel til stadighed op. Ved gentagne besøg i Danmark i forbindelse med udgivelsen af hæftet »Tro, håb og virkelighed« (1989) havde Edicio muligheder for at få flere informationer om den danske kultur og de tanker, som lå til grund for de frie skoler. Informationer, som gennem breve blev videreformidlet til venner og kolleger i Filippinerne. Mulighederne for at besøge forskellige skoler lå inden for rækkevidde, idet han var blevet inviteret til at besøge forskellige 
højskoler rundt om i Danmark i foråret 1991. Den 30. marts 1991 blev han inviteret til at holde et foredrag om kampen for menneskelighed og rettigheder på Brogården på Fyn. Arrangementet var et led i et påskehøjskolekursus, hvori temaet liv og død var det centrale, og Edicio havde mulighed for at opholde sig der i den uge, kurset varede.

Opholdet i Danmark fortsatte med besøg på andre danske højskoler, bl.a. Silkeborg og Grundtvigs højskole i Hillerød. Ved at lytte og ved at læse og samle litteratur erfarede Edicio, at den nordiske mytologi lå som en væsentlig del af Grundtvigs arbejdsområde. Han erindrede, at han allerede $\mathrm{i}$ sin barndom og ungdom havde stiftet bekendstskab med den nordiske mytologi, og at han dengang havde været meget optaget at den livsvisdom, der fandtes heri.

Edicio begyndte at indsamle yderligere oplysninger og skriftligt materiale, som kunne formidles tilbage til interesserede samarbejdspartnere i Filippinerne. Vigtigt var det at undersøge, hvilken fælles målsætning, danske højskoler havde, hvilken form for undervisning, der blev tilbudt eleverne, og hvilke udfordringer, de danske højskoler stod overfor.

»Jeg mindes, at jeg stadig var i tvivl om, hvilket indhold en evt. højskole skulle have, hvis det kunne blive en realitet at starte en sådan i Filippinerne. Det ville ikke være muligt at reproducere danskernes erfaringer - ej heller et tema om liv og død. Den filippinske befolkning er ikke så gammel udvendig, men er det i stedet ideni. De har behov for en ramme for forståelse af lidenskaben, døden, opstandelsen, men også en fornyelse af ånden.«

Efterhånden som dagene i Danmark gik, dannede der sig en lang række forestillinger om det danske samfunds struktur i 1800-tallet, om bøndernes vilkår og om Grundtvigs tanker om et folkestyre. Edicio blev specielt optaget af udsagnet »Uddannelse for livet «.

»Jeg ved ikke nøjagtig, hvad Grundtvig mente, men i mit tilfælde medførte dette udsagn, at jeg gik ind i dybere overvejelser. Hvorfor kun en uddannelse for livet. Hvorfor ikke en uddannelse af livet? Jeg havde andre rødder, kom fra en anden kultur, men følte alligevel, at jeg pludselig fik en orienterings- 
ramme. Grundtvigs navn havde jeg hørt i mange andre situationer. Jeg havde stødt på hans tanker uden på det tidspunkt at være vågen over for dem. Nu provokerede Grundtvigs tanker mig, fordi jeg så dem alle steder. Der måtte ligge noget i dem, som var universelt.«

\section{Første skriftlige informationer}

I takt med informationsindsamlingen og overvejelserne begyndte der langsomt at tegne sig nogle ideer, der muligvis kunne realiseres i den filippinske kultur. På grund af omstændighederne i landet ville det ikke være muligt for Edicio selv at starte en højskole, hvorfor det var absolut nødvendigt at forsøge at formidle viden om Grundtvig og om højskoletanken til de filippinske kolleger via fax og telefon. Begrundelsen for, at kolleger i Filippinerne blev orienteret om Grundtvig var, at der gennem Folkekirkens Nødhjælp blev åbnet mulighed for at ans $\varnothing$ ge om midler til at starte en højskole.

Overvejelserne måtte koncentrere sig om flere vidt forskellige områder: For det første var det nødvendigt at have en tæt kontakt til en interesseret person i Filippinerne, som ville være i stand til at starte en højskole, hvis en ansøgning blev imødekommet. Edicio de la Torre ville ikke selv - på grund af den politiske situation - kunne opholde sig i Filipinerne for at påbegynde arbejdet, hvorfor det var en absolut nødvendighed at formidle Grundtvigs tankegang om skolen for livet til en central person, som måtte anses for at være $\mathrm{i}$ stand til at starte en højskole på dette grundlag.

For det andet var det nødvendigt at skelne mellem uformel ikke kompetencegivende folkelig uddannelse og almindelig uddannelse: »På Filippinerne anses voksenuddannelse ikke for særlig politisk, den tager ikke kampen op for det undertrykte menneske eller mennesker uden magt, den har kun det for $\varnothing j e$, at mennesket kan for $\varnothing \mathrm{ge}$ sin indkomst ved at gå på en erhvervsskole, hvor man kan få kørekort eller lære at sy eller bruge en computer.« Desuden var det vanskeligt at oversætte begrebet 'højskole', således at begrebets betydning blev forstået rigtigt. High School ville give associationer til en gymnasieskole og ikke en skole med et bestemt filosofisk grundlag, hvor målet »var at gøre mennesker mere humane og bevidste om deres eget liv og deres egne muligheder.« 
For det tredje var det nødvendigt at finde et navn til højskolen. Navnet ville være af stor betydning for de mennesker, som skulle forsøge at formidle højskoleideen til kommende elever. Det skulle indeholde et budskab, som med det samme gav bønder og fiskere et indtryk af, at denne skole adskilte sig fra den etablerede undervisning, som mange af dem havde dårlige erfaringer med. Samtidig skulle navnet signalere, at skolen kunne tilbyde en undervisning, som tog udgangspunkt i deres egne livserfaringer, og at netop livserfaringer var et grundlag for at videreudvikle sig selv og lokalsamfundet.

Det var imidlertid nødvendigt i løbet af kort tid at få formuleret et idéoplæg, som kunne danne grundlag for en egentlig ansøgning om $\emptyset$ konomisk bistand.

»Måske var det godt, jeg pludselig stod i en situation, hvor jeg var under tidspres. Det betød, at jeg var nødt til at se ind i mig selv og besvare spørgsmålet om, hvorfor jeg var grebet af tanken om en højskole. Jeg var også nødt til at koncentere mig om at tænke på de mange, som havde kæmpet for ideen om et folkestyre og forsøge at klargøre alle disse tanker, så de kunne udmønte sig både $\mathrm{i}$ et navn, et formål og et indhold, der i sig rummede den kultur, jeg tilhørte.«

At skulle starte en højskole ville naturligvis indebære problemer og risici, men Edicio havde igennem mange år påtaget sig at være 'stifinder'.

\section{Mål}

Sent på foråret 1991 forelå det første idéoplæg. Navnet på den højskole, som søgtes oprettet, var Den Filippinsk-Danske Højskole eller Paaralang Bayan. Det indeholdt et budskab om, at uddannelsen skulle være for livet, nemlig det liv, som levedes rundt om i lokalsamfundene, og som var fundamentet for græsrodsledernes betydning og arbejde. Det langsigtede udviklingsformål var

a) at forbedre levestandarden

b) at $\emptyset g e$ mobiliseringen af fattige og undertrykte grupper

c) at $\varnothing$ ge demokratiseringen i lokalsamfundene og nationalt. 
Målgruppen var græsrodsledere fra udvalgte, afgrænsede landområder og byslum. Af projektbeskrivelsen fremgik det endvidere, at »det forventes, at græsrodslederne via den nye uddannelse vil være i stand til at organisere og mobilisere flere mennesker og bibringe dem en forståelse af, at deres aktive medvirken i lokalsamfundene er af største betydning for, at demokratiseringsprocessen også vil slå igennem på lokalt plan. « Endelig blev der stillet forventninger om, at befolkningen bedre ville være i stand til »at fastholde eksisterende rettigheder, forhandle med lokale myndigheder, få egne forslag gennemført og evt. selv gå ind i lokalpolitik for derigennem at få direkte indflydelse.« Projektperioden skulle være fra 1992 til 1995.

Det var væsentligt for Edicio, at højskoleprojektet ikke byggede på at stille spørgsmål om, hvad det var man skulle kæmpe mod, men derimod, hvad man skulle kæmpe for. Endvidere var det vigtigt, at arbejdet kunne ske så åbent som overhovedet muligt. Naturligvis skulle eleverne blive $i$ stand til at tage kritisk stilling til forhold i samfundet, men lige så vigtigt var det, at de fik udviklet deres kreativitet, således at de blev i stand til at se nye muligheder og løsninger på de alt for kendte problemer.

»Halvfems procent af den uformelle undervisning, der er blevet givet inden for de seneste år har sigtet mod at gøre mennesker i stand til at være kritiske. Imidlertid kan kreativitet virke langt bedre, idet der så forventes noget af dig selv. Det er én selv, som også skal være medvirkende til at forholdene ændres.«

\section{Formidling af den danske højskoletradition}

Formidling af Grundtvigs skoletanker til de filippinske samarbejdspartnere måtte på grund af tidspres ske via fax og telefon. Da der i Filippinerne på det tidspunkt var strømsvigt ti timer i døgnet, var selve formidlingsprocessen vanskelig - specielt når det tages $\mathrm{i}$ betragtning, at modtagerne i Filippinerne aldrig havde været i Danmark eller hørt om Grundtvig.

En af de personer, som interesserede sig for de første spinkle informationer om, hvad en dansk højskoles idégrundlag byggede på, var Marichu C. Antonio. En tre-siders fax præsenterede Grundtvig og den danske højskoletradition, og Edicio skrev endvidere, at 
Grundtvig var forfatter til mere 1000 salmer, som stadig blev sunget i Danmark. Endelig var Edicio optaget af Grundtvigs arbejde inden for kirke, uddannelse og kultur.

Marichu Antonio formidlede de tilsendte oplysninger videre til $\varnothing v$ rige interesserede, som lidt efter lidt fik et indtryk af, at en af mulighederne for at realisere drømmen om et reelt folkestyre var at starte i det små med at opbygge en folkehøjskole efter dansk inspiration.

\section{Udfordringer}

De mennesker, som var involveret i planerne om en højskole, var bevidste om, at de stod over for store udfordringer i det kommende arbejde.

\section{Den sociale, politiske og фkonomiske situation}

Den største udfordring var landets sociale, politiske og økonomiske situation. Fra 1965 til 1986 havde præsident Ferdinand Marcos' autoritære statsstruktur ført landet ud i fattigdom og blodige oprør. Da Corazon Aquino trådte til i 1986 var landet i en meget vanskelig situation socialt og politisk. Ca. halvdelen af befolkningen levede under sultegrænsen, og i landdistrikterne var der en ekstrem fattigdom, som ikke så ud til at blive forbedret trods Verdensbankens advarsler om, at regeringen bliver nødt til at arbejde på at udarbejde jordreformer, at arbejde på at $\emptyset$ ge beskæftigelsen blandt de fattigste og udarbejde effektive familieplanlægningsprogrammer.

\section{At motivere ledere blandt landbefolkningen}

Visionerne for højskolen om at få elever fra netop den fattige bondeog fiskerbefolkning, hvilket kunne vise sig at være vanskelig at gennemføre, fordi de voksne ville få problemer med at forlade deres jordbrug og deres familier. Det kunne blive vanskeligt at overbevise en fattig bonde om vigtigheden af et højskoleophold, hvis han var i tvivl om familiens overlevelse, mens han var væk. 
Disse problemer kunne på det tidspunkt ikke finde en løsning, men måtte være den udfordring, som en kommende højskole stod med. Det ville være nødvendigt at motivere ledere til at rejse på højskole i længere perioder og overbevise dem om, at et sådant ophold ville kunne bedre eller forandre deres livssituation på længere sigt. Det måtte være muligt at bevidstgøre dem om mulighederne for at danne græsrodsbevægelser og derigennem få den styrke, som gjorde dem i stand til at varetage de opgaver, der lå i lokalsamfundet.

\section{At overvinde tidligere erfaringer med undervisningssystemet}

Den fattige del af landbefolkningen tilhører de dårligst uddannede, og figurerer i statistikkerne blandt de 35\%, som afbryder den officielle uddannelse, inden der er gået seks år. De kommende kursister vil møde med dårlige erfaringer fra deres tidligere skolegang, hvis undervisningsmål er at formidle boglige kundskaber, og hvis krav om eksamen vejer tungt. Det officielle undervisningssystem havde ikke inddraget det filippinske kulturgrundlag eller de praktiske færdigheder i undervisningen, men arbejdede mod at kvalificere eleverne til et moderne teknologisk samfund, hvor karakterer og prøver var af afgørende betydning for et senere arbejde.

De voksne elever, som var højskolens målgruppe, ville møde tilbuddet om et højskoleophold med erfaringer fra et skolesystem, som ikke tilgodeså landbefolkningens behov for at kunne forbedre deres dyrkning af jorden, og deres behov for at kunne optimere deres egne livsvilkår.

Det ville være nødvendigt at gøre en stor indsats for at overbevise kommende ledere om værdien af et højskoleophold, som netop tog udgangspunkt i ledernes verden og i deres behov. Det ville endvidere være nødvendigt at tilrettelægge en undervisning, som klart adskilte sig fra den, de tidligere havde stiftet bekendtskab med.

\section{At selvstaendigg $\phi r e$ befolkningen}

En fjerde udfordring bestod $\mathrm{i}$ at overvinde 'den lille mands syndrom'. Gennem århundreder har Filippinerne været undertrykt af henholdvis spaniere, japanere og amerikanere. Den filippinske be- 
folkning har mange års erfaring i at føle sig underlegen i forhold til udefrakommende ledere. Til trods for at der i 1980'erne opstod en massiv modstand mod overgreb, var og er der i den filippinske befolkning dybtliggende forventninger om, at andre og mere magtfulde nationer må gøre noget for dem.

Denne forventning blev underbygget af de økonomiske midler, som udefra blev kanaliseret ind i landet til diverse landbrugs- og vandingsprojekter samt projekter, hvis mål var at søge at minimere fattigdommen. De kommmende højskoleelever kunne møde med den opfattelse, at dette projekt var endnu ét tilbud om, at andre skulle komme og løse deres problemer.

»Den filippinske befolkning i sig selv er måske i virkeligheden den største trussel for fremgang. De har oparbejdet en attitude, hvor det er helt naturligt at forholde sig afventende og blive ved at fremsætte spørgsmål om, hvad andre kan gøre for dem. Hvis ikke denne holdning bliver ændret, således at de begynder at spørge, hvad de kan gøre for sig selv, vil nok så mange højskoleprojekter ikke kunne ændre de fattiges livsvilkår«.

De involverede var bevidste om, at højskolen skulle være et tilbud om selvudvikling, men ikke en institution, som kursisterne kunne blive ved at trække på, hver gang der viste sig vanskeligheder $\mathrm{i}$ lokalsamfundene. Det måtte være skolens opgave at give eleverne så megen selvtillid, at de ville være i stand til selv at løse kommende problemer eller opbygge netværk, som de kunne trække på. Det ville være fejlagtigt, hvis de fik en opfattelse af, at højskoleprojektet var en ny fremmed hjælpeinstitution, hvorfra man kunne hente økonomisk bistand til at ændre lokale forhold. Dette var især vigtigt, fordi højskolen ellers ville komme til at fungere som en ny autoritet, hvor det var muligt at henvende sig for at få hjælp. Højskolen måtte arbejde på at gøre lederne selvstændige og uafhængige af højskolen.

\section{At finde en plads i de ikke formelle uddannelsestilbud}

En femte åbenlys vanskelighed bestod $\mathrm{i}$ at finde en plads $\mathrm{i}$ det ikke formelle udannelsesstystem. På baggrund af den ringe vilje fra regeringens side til at ændre på de bestående forhold inden for 'ud- 
dannelsessektoren har der fra NGO'ernes side været taget en lang række initiativer til ikke-formelle uddannelsestilbud inden for voksenuddannelserne. En stor del af disse ikke-formelle uddannelsestilbud støttes af hjælpeorganisationer i andre lande.

Uddannelserne er vidt forskellige, men søger at tage udgangspunkt i de vidt forskellige behov og problemer, der er rundt om i landet. Det drejer sig om problemer vedrørende landbruget eller problemer vedrørende vandingsprojekter. De ikke formelle undervisningstilbud anvender andre undervisningsmetoder end de officielle og forsøger i større udstrækning at tage udgangspunktet i folkets situation og de behov, der er for at uddanne sig med henblik på at indgå i de demokratiske beslutningsprocesser.

En undervisning, som skulle føre frem til et folkestyre, skulle have et andet sigte end at løse vandingsproblemer eller dyrkningsmetoder. Det overordnede formål - et folkestyre - måtte gennemsyre hele undervisningen, hvilket betød at undervisningen måtte tilrettelægges ud fra andre overordnede principper end dem, der lå til grund for de $\emptyset$ vrige ikke-formelle udannelsestilbud.

\section{At bevare de uddannede i landet}

En sjette udfordring var at sikre, at højskoleopholdet ville blive til gavn for det lokale samfund. Gennem mange år havde der været en tradition for, at de veluddannede rejste ud af landet - fortrinsvis til USA og Australien - for at skabe sig en fremtid der. Forældrene st $\varnothing$ ttede de unge i deres $\varnothing$ nske om at forlade landet ud fra en betragtning om, at de ville få svært ved at skabe sig en fremtid i et land præget af korruption, arbejdsløshed og bueaukrati. Endelig ville familien være bedre tjent med, at deres børn havde en indkomst $i$ udlandet, som gjorde det muligt at sende penge hjem til forældre og søskende. Desuden var der en vis form for prestige knyttet til at kunne fortælle, at ens børn arbejdede i udlandet.

Hvis højskolen skulle blive en realitet, var det vigtigt, at eleverne rejste tilbage til deres egen hjemegn for at fors $\varnothing$ ge at skabe bedre forhold i lokalområderne. Højskoleopholdet skulle således påvirke den enkelte til at forstå det ansvar, der lå $\mathrm{i}$ at være med til at ændre samfundet indefra, selv om dette kunne have lange udsigter. Nok skulle højskolen søge at fremme den enkeltes selvudvikling, men 
vigtigt var det, at denne selvudvikling blev anvendt inden for landets grænser.

\section{Politiske og religiøse forskelle}

En syvende udfordring var at overveje, om elevernes forskellige religiøse og politiske baggrund kunne være af betydning for et højskoleopholds forløb. Ville eleverne være i stand til at arbejde og bo sammen på trods af de til tider meget store forskelle i livssyn og menneskesyn? Ville de forskellige traditioner kunne ligge som et værdifuldt grundlag for samvær, eller ville disse i stedet kunne give anledning til problemer?

Udviklingen i Filippinerne havde til stadighed medført, at de forskellige stammer og religiøse grupper havde mere eller mindre synlige magtkampe. Ville disse fortsætte i højskolens regi, eller ville det være muligt at anvende de forskellige livsopfattelser som grundlag for oplysning, som kunne nedbryde de barriere, der måtte være?

\section{Sprogproblemer}

Til trods for at der undervises $i$ engelsk $i$ det officielle system ville det være vanskeligt at gennemføre en undervisning, hvor samtalen var et vigtigt element, fordi de færreste af eleverne ville være i stand til at udtrykke deres følelser og tanker på engelsk.

Det filippinske sprog er ikke bare ét sprog, men mange forskellige sprog. Det ville betyde, at lærere og elever kunne have vanskeligheder med at forstå hinanden indbyrdes. Selv om eleverne ville kunne forstå et oplæg givet på filippinsk ville det være et massivt $\emptyset$ nske for dem at kunne udtrykke deres overvejelser og tanker på deres eget sprog. Det ville stille store krav til sammensætningen af en lærerstab, hvis så mange sprog som muligt skulle kunne være repræsenteret blandt underviserne.

Erfaringerne fra det officielle undervisningssystem viste, at sprogbarrieren alene kunne være en massiv faktor for, at elever afbrød deres undervisning. Det ideelle ville være at samle elever fra samme område, således at de kunne tale sammen indbyrdes. 
Ud over de synlige udfordringer højskolen stod overfor, var der i samfundet især tre andre forhold, som var nødvendigt at inddrage i overvejelserne om udviklingen af et folkestyre.

For det første ville det være nødvendigt at give landbefolkningen en virkelig forståelse af, hvad begrebet fællesskab betød. »Hverken kirke, regering eller NGO'erne havde formået at bibringe befolkningen en fællesskabsfølelse, som rakte ud over det at gøre oprør «. Det ville være nødvendigt at få en forståelse af, at begrebet fællesskab havde en fundamental betydning for mulighederne for at ændre ved såvel politiske som sociale forhold - også når der kom tider, hvor det ikke var nødvendigt at gøre oprør i gaderne.

»Under Marcos var der en helt synlig figur at kæmpe mod, men der kommer tider, hvor der ikke er noget synligt fjendebillede, som kan samle en befolkning. Det er i sådanne tider fællesskabet virkelig skal stå sin prøve. Hvis ikke fællesskabsfølelsen når dybere end til oprøret, vil der opstå et ideologisk tomrum, den dag befolkningen virkelig skal til at vise, at de $\emptyset n s k e r$ at arbejde for et folkestyre.«

Endvidere havde mange NGO'er rundt om i landet efterhånden udviklet deres eget bureaukratiske system, mens deres egentlige mål var blevet nedprioriteret. En del NGO'er var blevet et system i systemet, hvilket ikke efterlod den fattige del af befolkningen i en tro på, at disse NG0'er arbejdede for at skabe bedre sociale forhold.

For det andet var landet $\mathrm{i}$ en fase, hvor det var nødvendigt at styrke den enkeltes og samfundets moral: »Det var som om den enkelte ikke kunne se, at hans ellers hendes handlinger, når det f.eks gjaldt korruption, fik betydning for hele landet. Det drejede sig om at redde sig selv uanset med hvilke metoder. Værdigheden eksisterede ikke mere, landet var sygt.« Nok havde dele af befolkningen vist, at de kunne gøre modstand, men det var vigtigt at den enkelte kom til at se sine handlinger i et større perspektiv. Korruption og tyveri gav den opvoksende generation en forkert forståelse af, hvordan et samfund skulle fungere. At få ændret moralopfattelsen hos hele befolkningen inklusiv embedsmænd og politikere ville være af afgørende betydning for fremtiden: „Giv folk minderne tilbage - det har 
været et heroisk folk, men vi befinder os i en mere og mere demoraliserende situation, hvor det mere drejer sig om at tilgodese egne behov end folkets behov. Værdigheden er forsvundet til fordel for grådigheden.«

For det tredie var en del af befolkningen af den overbevisning, at det ville være en umulig opgave at udvikle et folkestyre. Hvis forholdene i landet skulle ændres, måtte det ske gennem en stærk leder en diktator - som havde magt til at ændre samfundsforholdene radikalt. Et sådant $\emptyset$ nske udsprang af magtesl øshed. Mange havde fors $\varnothing \mathrm{gt}$ at kæmpe for bedre forhold, uden at de kunne se synlige resultater. De følte sig udmattede, følte at hele debatten om demokratisering tærede på deres kræfter, at det gik for langsomt, og at det kun endte i samtale uden at der egentlig skete de store ændringer: »Man bliver så udmattet af at holde møder hele tiden, og det er trættende hele tiden at være den, som skal forsøge at overbevise andre om, at det er nødvendigt for hele tanken om et folkestyre. Men det væsentligste må være at give den enkelte en følelse af, at han eller hun indeholder noget særligt, som kan udvikles, og som kan være afgørende for både den enkeltes $\emptyset$ nsker og drømme om frihed og ligeværdighed.«

For det fjerde havde der gennem århundreder været lagt vægt på, at kvinder var ansvarlige over for hjem og børn. Muligheden for at indgå i politisk arbejde var ringe, fordi det ville bryde med en lang række traditioner. Aquino var et synligt eksempel på, at kvinder kunne være politisk aktive, men den form for arbejde, hun udførte, kunne ikke anvendes som symbol for kvindefrigørelse. Det var vigtigt, at kvinderne blev bevidste om deres eget værd i en fase, hvor landet skulle fors $\varnothing \mathrm{ge}$ at realisere tanken om et folkestyre. Imidlertid ville det være en vanskelig opgave, idet det ikke drejede sig om at fremme den enkeltes muligheder for at få topposter inden for det bureaukratiske system, men i stedet om at organisere en kvindebevægelse, som kunne arbejde for ligeberettigelse inden for uddannelse, arbejde, løn osv.

En kommende højskole stod således overfor en række udfordringer, som på den ene eller den anden måde måtte inddrages $\mathrm{i}$ overvejelserne og planlægningen af det indholdsmæssige og det metodiske. 


\section{Højskolens arbejde}

I oktober 1992 blev det første højskolekursus gennemført. På baggrund af den usikkerhed, som såvel leder, lærere og elever udsatte sig selv for, ansås det for at være mest sikkert ikke at have et fast tilhørssted men derimod afvikle kurserne forskellige steder rundt om i lokalsamfundene. De enkelte temaers indhold var bestemmende for den metode, som blev anvendt ved undervisningen, men vigtigt var det at holde fast $\mathrm{i}$ det overordnede formål om, at oplysningen skulle komme fra livet og være oplysning for livet - og ikke for en elitær uddannelse. Alle var således klar over, at kursusopholdet ikke ville kvalificere dem til en stilling eller til et videre studium, lige som alle var bevidste om, at opholdet ikke blev afsluttet med eksamen. I kurset indgik følgende temaer:

\section{Filippinsk identitet}

Indgangsvinklen var at stille spørgsmål om den enkeltes navn. Hvorfra kommer navnet? Er fornavnet fx engelsk (George) og efternavnet spansk (Santos)? Hvornår og hvorfor begyndte de spanske og engelske navne at vinde indpas. Var det på grund af tvang fra overherredømmet, - eller var det befolkningen selv, som ønskede at få et udenlandsk navn? Gennem disse spørgsmål blev svarene givet: Spanierne indførte en lov, som betød, at alle skulle have spanske navne, og alle skulle døbes, hvis de ville have mulighed for at gå i skole. Mistede filippinerne på det tidspunkt deres egen identitet? Findes der en 'ren' filippiner? Eller er en filippiner i virkeligheden en blanding af flere forskellige kulturer?

\section{Kommunikation}

Undervisningen blev tilrettelagt med henblik på at kursisterne blev bevidst om, hvordan informationssystemet virkede, og hvilken betydning dette havde for deres eget liv og for samfundets udvikling. Der blev informeret om oplysning via radio og om teknikken. Eleverne skulle derpå selv forsøge at interviewe én eller flere af de øvrige elever med henblik på at få en erfaring i at stille (kritiske) spørgsmål og få belyst det, som lytterne (de øvrige elever) fandt var vigtigt og væsentligt. 
Endvidere blev tv-mediets betydning for oplysning belyst gennem eksempler. Hvordan kan tv være med til at forme en befolknings holdninger? Hvordan kan der gennem tv manipuleres med oplysninger? Hvilken rolle har tv for samfundsudviklingen?

Avisernes kommunikationsform blev gennemgået. Der blev aflagt bes $\emptyset \mathrm{g}$ på en avis, det blev muligt at se, hvordan en fax-maskine fungerede, og der blev givet eksempler på, hvordan stoffet udvælges og sættes op. Derefter var det op til eleverne at debattere, hvilket stof de mente var vigtigt og væsentligt at få bragt i en avis, og hvilken placering de enkelte nyheder skulle have for at tilgodese god og sober nyhedsformidling.

Afslutningsvis blev der gjort en indsats for at bevidstgøre kursisterne om, at det er altafgørende for deres videre arbejde, at de er i stand til at fremføre en sag både over for embedsmænd, politikere og den lokale befolkning. Hvordan præsenterer man sig selv. Hvordan virker kropssproget på andre? Hvordan lyttes der aktivt? Hvordan præsenterer man sig selv og sin gruppe over for andre? Hvordan kan højskoleopholdet anvendes til at uddanne andre?

\section{Kultur og religion}

Hvilke værdier er højt prioriteret i den filippinske kultur? Hvorved adskiller disse værdier sig fra de vesteuropæiske eller de amerikanske værdier? Indledningsvis blev det debatteret ud fra spørgsmålet om, at såvel spanierne som amerikanerne havde påvirket den filippinske kultur i så høj grad, at de oprindelige værdier var gået tabt, således at der ikke var forskel på at opholde sig i en storby i Spanien, i USA eller i Manilla. Imidlertid var det en almen erfaring, at når filippinerne rejste til udlandet blev de bevidst om, at der var afgørende forskel på, hvilke værdier der blev prioriteret højt eller lavt i de forskellige kulturer.

I 1960'erne fors $\varnothing$ gte amerikanere og filippinere at lave en tværkulturel analyse af de filippinske værdier og den måde, de kommer til udtryk på i almenmenneskelige forhold. De fandt frem til, at kendetegnene for filippinerne er den skamfuldhed, generthed, vrede eller sårethed, som kommer til udtryk over for mennesker, du kender godt. Ikke $\mathrm{i}$ form af ord eller handlinger men snarere som en sprogløs attitude - et udtryk i ansigtet. Kendetegnende er endvidere en attitude, 
som indirekte og ordløst fortæller budskabet »jeg vil gerne komme godt ud af det med dig, men jeg kan ikke.« Endelig blev der peget på, at filippineren ønsker at behage alle - selv udefra kommende herskere. De byder dem velkommen og affinder sig med det, som sker. I deres fors $\emptyset \mathrm{g}$ på at stå på god fod med alle vil de underlægge sig andres behov og ønsker. De smiler og ler af selv de værste og mest grufulde episoder, som et $\emptyset$ nske om at få det hele til at glide uden de store problemer.

At religion har en væsentlig indflydelse på landets kultur og struktur afspejler sig bl.a. i de forskellige religioners betydning for udviklingen rundt om på de forskellige øer. I alt fem forskellige religioner var repræsenteret på det første kursus. Det gav anledning til, at de enkelte kursister fik et indtryk af andre måder at tænke og leve på, lige som det betød at en lang række fordomme blev gennemdebatteret. Til trods for at den overvejende del af befolkningen er katolikker, er der til stadighed indbyrdes religionsstridigheder, som ofte kan komme til voldelige opgør.

\section{Kvindernes ligeberettigelse}

Det centrale i dette tema var, at den filippinske kultur var opbygget efter en patriarkalsk samfundsstruktur, og at det også derfor var vigtigt, at mænd blev bevidstgjort om deres ansvar for at være med $\mathrm{i}$ en forandringsproces: Ville en bonde - som i forvejen havde vanskeligheder ved at tale sin sag og overbevise andre - kunne være fortaler for, at kvinder skulle have lige ret og ansvar, når det gjaldt uddannelse og samfundsudvikling? Ville det være muligt at få mænd til at handle aktivt for at være med til at skabe forandring, eller ville deres opdragelse og daglige erfaringer være en uovervindelig hindring? Og hvordan ville deres ord og handlinger blive modtaget $\mathrm{i}$ deres egen landsby?

Den store udfordring bestod $\mathrm{i}$ at fors $\emptyset \mathrm{ge}$ på én og samme gang at inddrage elevernes erfaringer og se mulighederne for forandringer. Havde den enkelte erfaringer, som viste, at kvinder kunne handle frit? Var der en fundamental tro på, at mænd ikke bare var fysisk overlegne, men også psykisk overlegne? Hvad ville der ske, hvis kvinder fik de samme muligheder som mænd: Ville de forlade hjem og børn for at realisere sig selv, eller ville de i stedet bruge deres 
kræfter på at indgå i et ligeværdigt samarbejde for at forandre samfundet?

\section{$\emptyset$ konomi}

Det feudale system havde haft afgørende indflydelse på den enkelte bondes $\emptyset$ konomiske situation gennem århundreder. Trods lovændringer inden for landbruget var der ikke sket en væsentlig økonomisk fremgang for bønderne. De love, som var blevet vedtaget, havde været trykt og udgivet på engelsk, hvilket naturligvis var en væsentlig begrænsning for den enkelte bonde og den enkelte landsby.

Hovedspørgsmålet på kurset var at undersøge, hvordan den daglige $\emptyset$ konomi influerede på den enkelte families og på landbyens udviklingsmuligheder. Det drejede sig ikke om at gennemgå statistikker og tabeller, men i stedet at undersøge dagligdagen og begrundelserne for denne situation. Hvordan foregår afregningen for høstudbyttet? Hvilke fordele og ulemper medfører dette? Hvordan kan dette eventuelt ændres? Hvem opkræver skatter? Hvilke fordele eller ulemper er der ved andelsbevægelser? Hvilke økonomiske overvejelser må gøres, før andelsbevægelser kan etableres?

\section{Politik}

Dette emne blev gennemgået som skuespil, hvor deltagerne dramatiserede de forskellige perioder i landets udvikling på baggrund af spørgsmål som: Hvordan fik eliten deres huse? Hvordan fik de land at dyrke? Hvordan kom de til at beklæde centrale poster i det politiske system? Hvornår og hvorfor fik kvinder valgret?

Nogle af deltagerne spillede folket andre spillede ledere. Derved opstod der sideløbende en debat, hvor de forskellige aktører havde muligheder for at forsvare deres synspunkter.

\section{Folkets erkendelse af rettigheder og muligheder for indflydelse}

Dette tema blev gennemgået ved, at kursisterne tegnede deres drømme og visioner for et samfund i år 2002 ud fra spørgsmålene: 
Hvordan skal vi sammen arbejde for en social udvikling? På hvilken måde får du opfyldt dine drømme om det gode liv med og for andre?

På baggrund af disse tegninger blev der lavet kampagner og afstemninger, hvor det var muligt at anfægte hinandens synspunkter og debattere alternative forslag.

\section{Evaluering}

Det første seks-ugers kursus gav anledning til en lang række overvejelser og diskussioner lærerne indbyrdes.

»Vi vendte og drejede spørgsmålet om filosofien bag højskoletanken i forhold til kursets forløb. Hvis vi anså deltagerne for at være kommende lærere i deres egne landsbyer, måtte vi ændre opfattelse af lærer-elev forholdet. Så ville det være nødvendigt, at vi alle på skift var elever og lærere, som kunne give hinanden viden og indsigt.

Endvidere debatterede vi, om vor struktur havde været rigtig. Måske var det uden for det formelle undervisningsforl $\varnothing b$, den virkelige undervisning foregik. Nemlig på de tidspunkter om natten, hvor kursisterne talte med hinanden om deres liv og diskuterede højskoleophold og fremtiden. Vi havde ikke tænkt så meget på tid til det uformelle, så perioden havde været meget hektisk og meget struktureret.

Endvidere var det centralt for os nøje at overveje, hvordan vi kunne få reduceret lærerstaben og få deltagerne til at starte og lede en del af møderne, så de fik den praktiske erfaring med dette arbejde.«

Ud over overvejelserne om indhold og form havde det væsentligste problem for nogle af deltagerne været hjemvé. En del havde været nervøse for, hvordan det gik med deres familer og med deres jord. Der havde været mulighed for at rejse hjem efter fjorten dage, men i de sidste dag før afrejsen var der langsomt opstået den fællesskabsfølelse, som var af fundamental betydning for det videre forl $\varnothing b$. Det blev derved i stor udstrækning de $\emptyset$ vrige kursister, som gennem samtale overbeviste den enkelte deltager om at vende tilbage og gennemføre hele kurset. Et andet problem havde været, at ikke alle 
følte det væsentligt at lære om kommunikation og politik. De ønskede i stedet at lære om landbrug og dyrkningsmetoder.

\section{Besøg på danske folkehøjskoler}

Fra efteråret 1992 til foråret 1993 blev der i alt afholdt tre seks-ugers kurser samt flere korte kurser og work-shops. Lærerne havde haft mulighed for at læse om den grundtvigske højskoletradition og havde gennem debatter og diskussioner søgt at arbejde med den danske højskoletradition i den filippinske kultur ud fra de visioner og de mål, de havde for højskolen.

Det var nu tid at realisere det første af flere besøg til danske højskoler med henblik på, at flere i lærergruppen fik forståelse for Grundtvigs tanker om folkeoplysning.

Den 30. maj 1993 ankom fire af de filippinske højskolelærere til Danmark. bl.a. lederen Marichu C. Antonio. Programmet var omfattende og gav muligheder for at tale med en lang række mennesker, som hver for sig kunne bidrage til at formidle viden om den danske højskoletradition.

Lærerne havde forventninger om, at både den filippinske og den danske højskole havde det samme uddannelsessyn.

»Vi forudsatte, at der var nogle parallelle ideer tilfælles med Danmark, nemlig ideen om at uddanne et samfund snarere end at uddanne det enkelte menneske. Endvidere forudsatte vi, at samfundet lå til grund for uddannelsen, og en del af formålet med uddannelsen var at indbygge en vision om, hvordan samfundet fremover kunne indrettes med henblik på at skabe optimale forhold for alle.«

Ved besøgene rundt omkring på højskolerne fik lærerne langsomt et indtryk af, hvordan de danske højskolers fobindelser var med det omgivende samfund.

»Før i tiden havde skolerne meget tætte forbindelser til det samfund, hvori de var placeret, men med de ændrede $ø$ konomiske forhold i Danmark og ændringerne i samfundet, er 
skolerne mere og mere blevet øer frem for at være en organisk del af det omgivende samfund.«

En væsentlig forskel på den filippinske og den danske højskolemodel var at de danske elever kom fra hele landet, hvorimod det var vigtigt og væsentligt i Filippinerne, at højskoleeleverne kom fra samme område, og at højskolen var placeret i lokalsamfundet. Denne filosofi havde ligget til grund for at vælge at lave en 'mobil-højskole'.

Endvidere var det overraskende for lærerne at erfare, at den enkelte højskole har hvert sit formål og sigte:

»Nogle skoler har opbygget et kristent samfund, andre et politisk samfund, som tilsyneladende fungerer uafhængigt af det omgivende samfund. Måske er begrebet samfund-lokalsamfund blevet mere kompliceret i Danmark, og der lægges måske ikke vægt på nogen politisk eller geografisk enhed.«

Lærerne var forberedte på, at den danske befolkning havde helt andre livsvilkår end dem, de kendte til i Filippinerne, men alligevel blev de under deres besøg opmærksomme på en lang række forhold (bl.a. arbejdsløshed, flygtningeproblematikken), som gav anledning til at se på højskolernes virke ud fra disse synsvinkler.

"I Danmark bliver samfundsspørgsmål tilsyneladende ikke diskuteret voldsomt i i højskolen, hvilket overraskede mig en hel del. Vi fik det indtryk, at højskolen er blevet en social institution, og hvis højskolen er en social institution, behøver den ikke at give en fornuftig grund for sin eksistens. Det enkelte menneske er der og skal bare gøre, hvad han eller hun gjorde før på andre sociale institutioner. Man behøver ikke at forklare, hvorfor man er der. Højskolerne er der bare.

Eftersom den danske højskole i vore øjne er en social institution, kan den komme til at lide skæbne med samfundet, medmindre den bliver mere aktivistisk i sin egen forståelse af sin eksistens ved at prøve på at tage fat på mere samtidige spørgsmål i det danske samfund, f.eks. racisme, arbejdsløshed og spørgsmålet om social fremmedgørelse, som vi mødte hver dag på højskolen. 
På Filippinerne er initiativet med at oprette denne højskole et fors $\varnothing \mathrm{g}$ på at reagere over for nogle af de sociale realiteter, at være ansvarlig over for at gøre mennesker til herre over deres deres liv, hvor værdiløse, magtesløse, håbløse de end har været.

Måske er højskolerne i Danmark også var på vej til at tage aktiv ansvarlig del i udviklingen af det danske samfund. Måske kan man bruge et billede af en skov: En skov skal kæmpe for sit eget rum, den er nødt til at forny sig selv til enhver tid. Den skal sætte frø og spire for at skabe sit eget liv. Men en skov kan også blive en institution, som man blot går ind $\mathrm{i}$ og går ud af. Bedst er det, hvis der er et væld af stier, som hver især fører ud til det omgivende samfund.«

Begreberne ansvarlighed, medleven og demokrati blev gjort til genstand for mange overvejelser. Måske var højskolerne et eksperiment for en demokratisk forståelse forstået på den måde, at det var op til den enkelte, om han eller hun følte ansvarlighed over for vedtagne regler ( $\mathrm{fx}$ om sortering af affald, at tømme skaldespanden, hvordan han eller hun ville bruge sin tid? Spørgsmålet om ansvarlighed vedrørte også den tid, der blev anvendt på undervisning og den tid, der blev brugt til uformelle debatter. Lærerne oplevede, at der på nogle af de danske højskoler var meget lidt tid, som ikke var organiseret af en lærerstab. Omvendt fandtes der også skoler, hvor eleverne selv skulle være ansvarlige for at planlægge aktiviteter og egne værksteder. Det var deltagerne selv, som skulle beslutte, hvordan de ville tilrettelægge et bestemt forløb, og de stod også med det endelige ansvar. Dette gav mulighed for refleksion:

»På Filippinerne har vi altid kæmpet for tid, som ikke var struktureret, men vi har haft tilbøjelighed til at glemme spørgsmålet om ansvarlighed. Vi har haft en tilbøjelighed til at blive revet med af det indhold, vi ønsker at diskutere i skolen, men vi optager al den tid, der er, - eller så godt som. Jeg tror, at det er vigtigt at vores eksperiment om demokrati - som højskolen er - i højere grad giver eleverne muligheden for at kontrollere deres egne liv. Derved kan de lære at tage korrekte beslutninger, bruge de ressourcer, som lægges frem for dem, og skabe deres eget demokratiske liv på deres egne niveauer.« 


\section{Højskolens fortsatte virke}

Hvordan højskolen vil udvikle sig i de kommende år er naturligvis usikkert, blandt andet fordi højskolens virksomhed er afhængig af den politiske udvikling i landet.

Det er ikke uden grund at det danske flag indgår side om side med det filippinske flag i højskolens logo. Højskolens fremtid er ikke blot er afhængig af den økonomiske hjælp men i høj grad også af den bevågenhed som danskere kan vise højskolen.

Vi har svært ved at forbinde Grundtvigs skoletanker med frygt, sult, tortur og drab. Vi har svært ved at forstå, at vejen til et folkestyre skal være brolagt med så store udfordringer og så megen smerte. Vi har jo muligheden for at deltage i højskolekurser, hvor vi kan »besinde os på livet « og lære om meditation og yoga. Det vil tage mange år før fillipinske højskoler kan tillade sig tilbyde sådanne kurser - men deres visioner går også i en anden retning:

»Min drøm er, at højskolen om ti år ikke er en alternativ uddannelse, men at uddannelsen anerkendes ikke blot af staten, men også af folket, således at de kan se nødvendigheden af denne form for uddanelse. Min drøm er, at der er en samlet interesse for at udbygge højskoletanken...

På den måde ville højskolen få rødder i det pågældende lokalsamfund. Lærere fra landsbyskolen, højskolelærere, børn, unge og gamle kunne mødes til en lang række aktiviteter, som hele landsbyen kunne have glæde af. Det kunne både dreje sig om helt praktiske, jordnære ting, men også om politiske og sociale spørgsmål. Derigennem ville de få mulighed for at se deres indsats udmønte sig i noget konkret, og de ville se samfundet blomstre.«

Noter

1. Folkekirkens Nødhjælps Projektoplysningsformat af 15.-3.-1991

2. Torre, Edicio de la: Touching Ground Taking Root. Theological and Political Reflections on the Philippine Struggle. Socio-pastoral Institute, Phillipines, 1986.

3. Ibid., s. 1. 
4. Ibid., s. 3 .

5. Torre, Edicio, de la: Folkemagt - hvad er det? I: Kontakt nr. 2 Filippinerne. Farvel til folkemagten. Mellemfolkeligt Samvirke, 1988/89.

6. Ibid. Den resterende del af artiklen bygger på interviews med Edicio de la Torre samt med højskolens leder, lærere og elever. Interviewene blev gennemført i Filippinerne i juni og juli 1993. 